\title{
LABOR LAW: SUPREME COURT REFUSES SPECIFIC PERFORMANCE OF "NO-STRIKE" PROVISION IN COLLEGTIVE BARGAINING AGREEMENT
}

$F_{\text {rom the time the Supreme Court ratified the policy of federal }}$ judicial enforcement of labor-management agreements through Section 301 (a) of the Labor Management Relations Act of 1947 (TaftHartley), ${ }^{1}$ an unresolved problem has lingered on the judicial horizon. Will a request for specific enforcement of a "no-strike" clause under section 301 (a) prevail in a direct conflict with Section 4 of the Norris-LaGuardia Act, ${ }^{2}$ which forbids federal courts to issue injunctions in labor disputes? Initial litigation of this question resulted in conflicting circuit court decisions.s Last term in Sinclair Ref. Co. v. Atkinson, the Supreme Court, in a five to three decision, settled this conflict by unequivocally holding that Section 301 (a). of

\footnotetext{
2."Suits for violation of contracts between an employer and a labor organization ... may be brought in any district court of the United States having jurisdiction of the parties. ..." Labor Management Relations Act (Taft-Hartley Act) $\$ 301$ (a), 61 Stat. 156 (1947), 29 U.S.C. 185 (a) (1958).

In Textile Workers Union of America v. Lincoln Mills, 353 U.S. 448 (1957), the Court construed the above quoted section to support enforcement of labor agreements by both state and federal courts. The Lincoln Mills case was soon followed by the "Triology" cases which clarified and reaffirmed the Court's position that \$301 (a) expressed a federal policy to enforce labor-management agreements. See United Steelworkers of America v. American Mfg. Co., 363 U.S. 564 (1960); United Steelworkers of America v. Warrior \& Gulf Nav. Co., 363 U.S. 574 (1960); United Steelworkers of America v. Enterprise Wheel \& Car Corp., 363 U.S. 593 (1960).

2 "No court of the United States shall have jurisdiction to issue any restraining order or temporary or permanent injunction in any case involving or growing out of any labor dispute to prohibit any person or persons participating or interested in such dispute (as these terms are herein defined), from doing, whether singly or in concert, any of the following acts:

(a) Ceasing or refusing to perform any work or to remain in any relation of employment. .." The Norris-LaGuardia Act (Anti-Injunction Act) $\$ 4$, 47 Stat. 70 (1982), 29 U.S.C. \$ 104 (1958).

'The first, second, and seventh circuits had held that $\S 301$ (a) of Taft-Hartley did not repeal $\$ 4$ of Norris-LaGuardia. W. L. Mead, Inc. v. Teamsters Union, Local 25, 217 F.2d 6 (Ist Cir. 1954) (repeals by implication are not favored); A. H. Bull S.S. Co. v. Seafarers' Int'l. Union, 250 F.2d 326 (2d Cir. 1957) (breach of "no-strike" clause is a labor dispute and $\$ 301$ (a) of Taft-Hartiey does not repeal Norris-LaGuardia prohibition against issuance of injunction); Sinclair Ref. Co. v. Atkinson, 290 F.2d 312 (7th Cir. 1961) (instant case).

The tenth circuit, on the other hand, held that $\S 301$ of Taft-Hartley gave federal district courts the power to issue injunctions against picketing in violation of nostrike clauses notwithstanding $\$ 4$ of Norris-LaGuardia. Teamsters Union, Local 795 v. Yellow Transit Freight Lines, Inc., 282 F.2d 345 (10th Cir. 1960), rev'd per curiam 370 U. S. 711 (1962).
}

+370 U.S. 197 (1962). 
the Taft-Hartley Act did not "impliedly repeal". Section 4 of the Norris-LaGuardia Act in labor-management contract enforcement cases, and, therefore, no injunction could issue to specifically enforce a "no-strike" provision of a collective bargaining agreement:

Sinclair Refining Company (Sinclair) and the Oil, Chemical and Atomic Workers International Union (Union) were parties to a collective bargaining agreement which provided for compulsory arbitration of certain "grievances"' and also contained a "no-strike" pledge on the part of the union. Due to Union's alleged violation of the no-strike clause, ${ }^{6}$ Sinclair brought this action under Section 301 (a) of Taft-Hartley, praying for temporary and permanent injunctions restraining Union and its members from breaking the nostrike clause in the future. The district court granted Union's motion to dismiss' on the ground that the relief sought was prohibited by Section 4 of the Norris-LaGuardia Act, and the Court of Appeals for the Seventh Circuit affirmed the dismissal.8

The Norris-LaGuardia Act generally provides stringent procedural limitations on the issuance of injunctions in any case arising from a labor dispute. Section 4 of the act categorically bans issuance of injunctions against strikes and work stoppages in labor disputes. ${ }^{\circ}$ This act was passed by an aroused $72 \mathrm{~d}$ Congress determined to immunize labor from management's ability to invoke judicial intervention in labor's efforts to organize, bargain collectively, and obtain collective bargaining agreements. ${ }^{10}$ Since its passage, the governmental hands-off policy it expresses has given way in contemporary

Arbitration was required over any difference regarding wages, hours or working conditions arising within any plant or region of operations. 370 U.S. at 197.

- Sinclair alleged that the union had violated their contract on nine separate occasions by engaging in strikes and work stoppages over matters which were the proper subject of arbitration under the agreement. Sinclair contended that Union's past violations demonstrated their complete disregard of their contractual obligations and consequently there was a great likelihood of similar breaches in the future from which Sinclair had no adequate remedy at law to protect itself. 370 U.S. at 197.

"Sinclair Ref. Co. v. Atkinson, 187 F. Supp. 225 (N.D. Ind. 1960).

${ }^{8}$ Sinclair Ref. Co. v. Atkinson, 290 F.2d 312 (7th Cir. 1961).

The Norris-IaGuardia Act (Anti-Injunction Act) $\$ 4,47$ Stat. 70 (1932), 29 U.S.C. $\$ 104$ (1958).

${ }^{10}$ The Norris-LaGuardia Act is the epitome of the philosophy that the civil law through the use of the injunction has no useful function in the field of labor rela. tions. Cox, Reflections Ujpon Labor Arbitration, 72 HARV. L. REv. 1482, 1484.85 (1959); Cox, Current Problems in the Law of Grievance Arbitration, 30 RockY MT. L. REv. 247, 253 (1958); Stewart, No-Strike clauses in the Federal Courts, 59 Mich, L. REv. 673, 676 (1961); Comment, 70 YALE L.J. 70, 96 (1960); Note, 18 WASH. \& LEE L. Rev. 329, 333 (1961). See generally SMith \& Merrifield, CASEs on Labor RELA. THONS LAw, \$3.12 (2d rev. ed. 1960). 
labor legislation to a more regulatory approach.11 Contrary to the situation that existed in 1932, many current labor disputes are over problems that arise after a collective bargaining agreement already has been signed.12 Consequently, Congress has become increasingly concerned with peaceful enforcement of labor-management agreements and avoidance of the crippling effects of labor disputes. In order to facilitate the enforcement of labor-management contracts, Congress provided in Section 301 (a) of Taft-Hartley that suits for contract violations could be brought in any federal district court having jurisdiction of the parties. Enforceable arbitration agreements, as a result, have loomed large in importance and have been called the "king-pin"13 of federal labor policy.

If read alone, the broad grant of authority in section 301 (a) would clearly seem to imply that federal courts can use all remedies at their disposal, including injunctions, to enforce collective bargaining agreements. However section 301 (a) cannot be read alone; it must be read within the context of its own historical development as well as in conjunction with the pertinent provisions of other legislation, including the clear commands of the Norris-LaGuardia Act. The legislative history of section 301 (a) indicates that at the time of its passage, Congress was fully aware of the evils of labor injunctions and of the protective prohibitions of the Norris-LaGuardia Act.14 Lower federal courts have generally recognized this awareness and accordingly have held that section 301 (a) was not meant as

${ }^{21}$ See Comment, Labor Injunctions and Judge-Made Labor Law: The Contemporary Role of Norris-LaGuardia, 70 YALE L.J. 70 (1960), where it is stated that "... congressional policy appears to have disregarded [the] aims [of Norris-LaGuardia], since the regulatory framework created under the new acts assigns far-reaching adjudicatory and enforcement responsibilities to the federal courts." See. also Cox, Gurrent Problems in the Law of Grievance Arbitration, 30 ROCKY MT. L. REv. 247, 254 (1958), where it is stated that "to an undefined extent the Norris-LaGuardia Act has become an anachronism."

${ }^{12}$ Stewart, supra note 10, at 677.78, states that Congress in Norris-LaGuardia intended to free unions from equitable remedies in order to give them power to extract an agreement in writing from the employer, and thus Norris-LaGuardia was not intended to free unions from the one effective remedy after agreement was reached.

13370 U.S. at 226. See also United Steelworkers of America v. American Mfg. Co., 363 U.S. 564 (1960); United Steelworkers of America v. Warzior \& Gulf Nav. Co., 368 U.S. 574 (1960); United Steelworkers of America v. Enterprise Wheel \& Car Corp., 363 U.S. 593 (1960); Textile Workers of America v. Lincoln Mills, 353 U.S. 448 (1957).

16 In his dissenting opinion in the instant case Mr. Justice Brennan concedes that Congress "considered and rejected the advisability of repealing the Norris-LaGuardia Act insofar as suits based upon breach of collective bargaining agreements are concerned. . . " "370 U.S. at 220. For a history of section 301 (a) see Comment, 70 YAIE L.J. 70 (1960). 
a sub silentio authorization of injunctive relief. 16 The Supreme Court, however, while never having addressed itself directly to the inevitable conflict which would arise between Section 4 of the Norris-LaGuardia and Section 301 (a) of Taft-Hartley, had implied that it would recognize limited exceptions to the unequivocal noinjunction mandates of Norris-LaGuardia if they fell within the policy confines of Section 301 (a) of Taft-Hartley. Such inferences were reasonably justifiable from implications in two earlier landmark decisions, Brotherhood of R.R. Trainmen v. Chicago River \& Ind. Ry. ${ }^{16}$ and Textiles Workers of America v. Lincoln Mills. ${ }^{17}$

In the Chicago River case, the Court held that Section 4 of Norris-LaGuardia was not intended to prohibit injunctive relief against a strike when compulsory arbitration was directed under the Railway Labor Act. In so holding, the Supreme Court recognized that the Norris-LaGuardia Act and the Railway Labor Act were integral parts of the pattern of national labor legislation and, consequently, the two acts had to be accommodated "so that the obvious purpose in the enactment of each is preserved."18 In Lincoln Mills, the Court sanctioned specific enforcement of a collective bargaining agreement to arbitrate grievances. ${ }^{10} \mathrm{Mr}$. Justice Douglas further stated that the substantive law to be applied in suits

${ }^{15}$ A. H. Bull S.S. Co. v. Seafarers' Union, 250 F.2d 326 (2d Cir.), cert. denied, 355 U.S. 982 (1957); W. L. Mead, Inc. v. Teamsters Union, Local 25, 217 F.2d 6 (Ist Cir. 1954); In re Third Ave. Transit Corp., 192 F.2d 971 (2d Gir. 1951); Baltimore Contractors, Inc. v. Carpenters Dist. Council, 188 F. Supp. 382 (E.D. La. 1960); Alcoa S.S. Co. v. McMahon, 81 F. Supp. 541 (S.D.N.Y. 1948), aff'd per curiam, 173 F.2d 567

- (2d Cir. 1949), cert. denied, 338 U.S. 821 (1949); Sound Lumber Co. V. Lumber Workers, Local 2799, 122 F. Supp. 925 (N.D. Cal. 1954). Contra: Teamsters Union, Local 795 v. Yellow Transit Freight Lines, Inc, 282 F.2d 345 (10th Cir. 1960), rev'd per curiam, 370 U.S. 711 (1962); American Smelting \& Ref. Co. v. Tacoma Smeltermen's Union, Local 25, 175 F. Supp. 750 (W.D. Wash. 1959); Johnson \& Johnson v. Textile Worker's Union, 184 F. Supp. 359 (D.N.J. 1960).

Cases where courts specifically enforced arbitration clauses are the weight of authority, but where anti-strike injunctions were sought the weight of authority is contrary. Comment, The Lincoln Mills Case and Specific Enforcement of No-Strike Clauses in the Federal Courts, 25 U. CHr. L. REv. 496, 501 (1958).

${ }^{10} 353$ U.S. 30 (1957). $\quad 17353$ U.S. 448 (1957). $\quad{ }^{18} 353$ U.S. at 40.

${ }^{10} \mathrm{Mr}$. Justice Douglas pointed out that failure to arbitrate was not one of the kinds of acts listed in $\S \leqslant$ of Norris-LaGuardia and thus made unenjoinable by federal courts, and further that Section 8 of Norris-LaGuardia indicates a federal policy in favor of arbitration; in Lincoln Mills he also made his famous and much debated quid pro quo statement:

Plainly the agreement to arbitrate grievance disputes is the quid pro quo for an agreement not to strike. Viewed in this light, the legislation does more than confer jurisdiction in the federal courts over labor organizations. It expresses a federal policy that federal courts should enforce these agreements on bchalf of 
under section 301 (a) is federal law which the courts must "fashion"20 from the policy of our national labor law.

The specific question still left unsettled, however, was, whether a federal court could issue an injunction to compel specific performance of a "no-strike" clause under Section 301 (a) of Taft-Hartley, notwithstanding the express language in Sections 1 and 4 of NorrisLaGuardia. ${ }^{21}$-Most commentators had anticipated that on the basis of the implications in Chicago River and Lincoln Mills, the Supreme Court would hold that a no-strike clause was specifically enforceable.22

In Sinclair, however, the majority opinion did not follow prognostications of the commentators. Short shrift was made of the contention that the term "labor dispute" in the Norris-LaGuardia Act does not include disputes arising out of a union's refusal to abide by terms of a collective bargaining agreement. - Mr. Justice Black stated that Sinclair's restrictive definition of "labor dispute" rested more on what many commentators think the law should be than upon a correct judicial interpretation of the express language. of Section 13 of the Norris-LaGuardia Act. The Court found that to issue an injunction to enforce a "no-strike" clause would run directly counter to the specific language of Section 4 of NorrisLaGuardia. ${ }^{23}$ The majority concluded from a lengthy examination

or against labor organizations and that industrial peace can be best obtained only in that way. 353 U.S. at 455 .

For a critical analysis of the majority's dismissal of the constitutional issue in Lincoln Mills, see Bickel \& Wellington, Legislative Purpose and the Judicial Process: The Lincoln Mills Case, 7I HARV. I. REV. 1 (1957). It has been suggested that the quid pro quo statement shows that the Court believed no-strike clauses were also subject to specific enforcement. Comment, 25 U. CHr. L. REv. 496, 499 (1958).

20353 U.S. at 456.

${ }^{21}$ For a discussion of four possible positions that can be taken in respect to the conflict between $\$ 30 \mathrm{I}$ (a) of Taft-Hartley and $\$ 4$ of Norris-LaGuardia, see $25 \mathrm{U}$. CFr. I. REv. 496 (1958).

${ }^{22}$ GREGORY, LABOR AND THE LATV 455-56 (2d rev. ed. I958); CoX, supra note 11, at 252-56; Gregory, The Law of the Collective Agreement, 57 MIcH. L. REV. 635, 637, 645 (1959); Hays, The Supreme Court and the Labor Law, October Term, 1959, 60 Colvur. L. REv. 901, 918 (1960); Stewart, supra note 10 at 683; Comment, 25 U. CFI. L. REv. 496,506 (I958). But see Feinsinger, Enforcement of Labor Agreements-A New Era in Collective Bargaining, 43 VA. L. REv. 1261 (I957), for possible support of Sinclair.

One court stated that "If that [Lincoln Mills] language means what it plainly says, surely simple justice and common fairness would dictate that sauce for the goose be such for the gander." American Smelting \& Ref. Co. v. Tacoma Smeltermen's Union, 175 F. Supp. 750, 754 (W.D. Wash. 1959). Accord, Teamsters Union, Local 795 v. Yellow Transit Freight Lines, Inc, 282 F.2d 345 (10th Cir. 1960).

is Accord, Cox, supra note 11, at 253, where the author agrees that to enjoin a strike 
of the legislative history of Section 301 (a) of the Taft-Hartley Act that Gongress deliberately chose not to repeal the Norris-LaGuardia Act when it considered section 301 (a). Hence, reasoned the Gourt, neither was section 301 (a) meant to "repeal" section 4 in contract enforcement cases, and, accordingly, the courts were not intended to have the power to " 'accommodate' that act out of existence." In distinguishing the Chicago River case, the Court pointed out that there the strike was called in defiance of a required duty to arbitrate imposed by the Railway Labor Act; while in the instant case, a quite different law was involved which did not compel a specific, exclusive method for settling disputes. Lincoln Mills was distinguished on the ground that a mandatory injunction to carry out an agreement to arbitrate did not enjoin any of the kinds of conduct which NorrisLaGuardia withdrew from the injunctive powers of the U.S. courts. The majority opinion concluded by saying that section 301 (a) does not conflict with the anti-injunction provisions of Norris-LaGuardia because the employer can still obtain an order compelling arbitration. ${ }^{25}$ The Court states that if it is desirable for the mandates of the Norris-LaGuardia Act to be changed, it is up to Congress to do it.

The dissent, ${ }^{2 B}$ while agreeing that Section 301 (a) of the TaftHartley Act did not repeal Section 4 of the Norris-LaGuardia Act, argued that the two sections do coexist and do apply in the instant case in apparently conflicting senses. Consequently, Mr. Justice Brennan asserted that the Court should have resolved this conflict through accommodation as was done in the Chicago River case and, in this instance, allow the issuance of an injunction. ${ }^{27}$ The dissent pointed out that the Court could have arrived at a different

would fly in the face of the plain words of $\$ 4$ of Norris-LaGuardia. See also Baltimore Contractors, Inc. v. Carpenter's District Council, 188 F. Supp. 382, 383 (E.D. La. 1960), where the court stated that "it is one thing to get around procedural rules when they appear 'inapposite' and quite another to ride roughshod over a categorical prohibition."

at 370 U.S. at 209.

${ }^{25}$ See Atkinson v. Sinclair Ref. Co., 370 U.S. 238 (1962); Drake Bakeries v. Local 50, American Bakers \& Confectionary Workers, 370 U.S. 254 (1962). See also Isaacson, The Grand Equation: Labor Arbitration and the the No-Strike Glause, 48 A.B.A.J. 914, 917 (1962).

${ }^{20} \mathrm{It}$ is interesting to note that Justice Douglas, who wrote the majority opinion in Lincoln Mills, sided with the dissenters in the instant case; this presumably indicates that he felt the majority's attempts to distinguish Lincoln Mills were not successful.

${ }_{27} 370$ U.S. at 216. Cox, supra note 11, at 254-56, points out that there is a judicial tendency to curtail the anti-injunction law in favor of implementing later legislation creating legal rights and duties, and states that reading an exception in Norris. LaGuardia will not necessarily revive the evils of the Iabor injunction. 
result without frustrating the basic intents of either act if it had interpreted the legislative history differently. ${ }^{28}$ Since Section 301 (a) of Taft-Hartley grants concurrent jurisdiction to state and federal courts to enforce labor-management agreements, Mr. Justice Brennan called attention to the uncertainty that the Sinclair decision creates concerning the role of the state courts relative to enforcement of collective bargaining agreements under Section 301 (a) of TaftHartley.90

Initial reaction to Sinclair has been generally unfavorable. ${ }^{30}$ The most common criticism seems to be that the decision offends fundamental fairness by granting dissimilar and unequal remedies. ${ }^{31}$ Labor can specifically require management to arbitrate a dispute, but

${ }^{28}$ Rice, A Paradox of Our National Labor Law, 34 Marg. L. REv. 239, 248 (1951), asserts there is nothing in the legislative history of Norris-LaGuardia itself that indicates whether it was intended to restrict remedies for breach of contract duties. Cox, supra note 11, at 255, argues that the situation in Chicago River. was an exact parallel to the type involved in the instant case. See also Stervart, stipra note 10, at 679.

${ }^{20}$ If a state court can still issue injunctions to enforce no-strike clauses, then employers can be expected to rush to them and the Lincoln Mills command to the federal courts to fashion a uniform, coherent body of substantive federal law will be dealt a harsh blow. On the other hand, if a state court is precluded by the decision in the instant case from issuing injunctions to enforce no-strike clauses, an important remedy that existed before the decision in this case will be denied employers. 370 U.S. at 226-27. Application of the Sinclair rule to preclude state courts from granting injunctions is not unlikely. See Local 174, Teamsters Union y. Lucas Flour Co, 369 U.S. 95 (1962) (under $\$ 301$ (a) a suit for violation of a collective agreement in either a federal or a state court is governed by federal law).

Compare McCarroll v. Los Angeles County Dist. Council of Carpenters, 49 Cal.2d 45,315 P.2d 322 (1957), where a contractor sued to enjoin a strike in breach of a collective bargaining agreement. Traynor, $J$., held that merely because the suit could have been brought in a federal court and the federal court would have been precluded from issuing an injunction did not stop the California courts from issuing injunctions. Some of the ramifications of this interesting case are discussed in 71 HARV. L. Rev. 1172 (1958). See also Isaacson, supra note 25, at 919; Comment, 18 WASH. \& LEE L. REY. 329, 335 (1961); Comment, 70 YAIE L.J. 70, 100 (1960).

so "This week's decision, in maintaining a patent discrimination, plus a morally offensive law, leaves the state courts to restore some measure of justice and ethics to the situation. And since this will create a crazy quilt of conflicting decisions, the Supreme Court's reversion this week from moral arbiter of the nation to laissez-faire tolerator of a basic wrong has struck two crippling blows at arbitration as a settlement process in labor disputes." Krock, In the Nation-Sauce for One Side Only in Labor Contracts, N.X. Times, June 22, 1962, §L, p. 24. See also U.S. News \&: World Report, July 2, 1962, p. 88.

${ }^{31}$ See Comment, 25 U. Car. L. REv. 496, 504 (1958); U.S. News \& World Report, supra note 30 .

Although Norris-LaGuardia was intended mainly as a protection for union and employee activities, where its terms can be read to include employer conduct that conduct should be protected. Iocal 205, United Elec. Workers v. General Electric Co., 233 F.2d 85 (1st Cir. 1956), aff'd 353 U.S. 547 (1957). See also Textile Workers of America v. Lincoln Mills, 353 U.S. 448 (1957), where the Supreme Court by its 
management cannot enjoin labor's violation of its no-strike pledges in event of a dispute.

Certainly. the dissent and the commentators are justified in charging that a great blow has been dealt to the strongly encouraged policy of grievance arbitration. The employer will, of course, still have the remedies of damages and specific enforcement of arbitration agreements, ${ }^{32}$ but the protections afforded by these remedies when the union is free to strike without judicial interference are not of the variety most conducive to persuade management to agree to grievance arbitration in return for a no-strike clause..$^{33}$ Consequently, the ideal of a coherent body of substantive law to be developed by federal courts on enforcement of collective bargaining agreements has been tarnished.

It is submitted that although the decision in Sinclair is probably required under general rules of strict statutory construction and can be defended on grounds of judicial restraint, it is not a happy result. Nevertheless, some good may come of the instant decision if it serves as a stimulus to force Congress to reconsider and reevaluate the role of Norris-LaGuardia in light of modern day labor-management relations.

concern with whether Norris-LaGuardia prohibits issuance of an injunction requiring an employer to arbitrate seems to accept the idea that Norris-LaGuardia can also be used by employers. Consequently, one wonders what the Court would hold if an employer, in violation of a "no-lockout" clause, closed down his plant when it came time to arbitrate a grievance; would specific performance of the "no-lockout" clause be granted the union?

32 Supra note 25.

as The only affirmative obligation that flows from the union to the employer is the no-strike clause, and this clause is of little value unless it is enforced. Stewart, supra note 10; at 673-74. 33 RockY MT. L. REv. 435 (1961), asserts that damages for breach of a no-strike clause are inadequate. 